\title{
Why would a leading global reinsurer be interested in nutrition?
}

\author{
(9) $(1) \Theta$ OPEN ACCESS \\ The benefits of better diets extend beyond health
}

\author{
John Schoonbee global chief medical officer, Swiss Re, Emile Elefteriadis head of life and health \\ products Canada, Swiss Re
}

\begin{abstract}
"Let food be thy medicine and medicine be thy food." More than 2000 years ago Hippocrates already recognised the link between nutrition and health. Today this link has an ever growing effect on our global society and, in particular, on insurers, who provide a financial safety net for people around the world. In the US, the world's largest life insurance market, insurers provide nearly $\$ 2 \mathrm{tn}$ in coverage for individual life policies.
\end{abstract}

When determining long term mortality risk to provide this cover, actuaries have for decades factored in a price reduction based on the assumption that life expectancy will continue to increase. This is termed a "mortality improvement" assumption and can be locked in for many years when there are long term guarantees. If actual mortality improvements or the trend of living longer should slow down or reverse, it would have a substantial effect on the life insurance industry. Consumers too, would feel the pain, having to pay more for new life insurance than they do today.

In the UK, mortality has improved at a slower rate since 2011 than in the previous decade, according to the Continuous Mortality Investigation 2016 report. $^{2}$

In the US, adult life expectancy in the general population has fallen for two consecutive years. ${ }^{3}$ This has not occurred since the 1960s. The subsequent focus has been on the increase in deaths from non-natural causes such as opioid overdose. Yet the key contributing factors for many of the usual causes of death listed, like heart disease or stroke, are hard to determine and are typically not well recorded.

\section{Diabetes}

A recent study noted that diabetes is recorded as a cause of death in only $3.3-3.7 \%$ of deaths. ${ }^{4}$ However, when the researchers examined the data more closely, the percentage of deaths attributable to diabetes was three times higher at 11.5-11.8\%.

It is even more worrisome to see type 2 diabetes rates continue to soar not just in Western countries but also in developing countries, including many in Asia. India and China now have the highest number of people with type 2 diabetes. In China, almost $15 \%$ of adults living in cities today have type 2 diabetes, ${ }^{5}$ and projections of global prevalence do not indicate a slowdown. ${ }^{6}$

In our ageing world, dementia and Alzheimer's disease are a growing concern and burden to families and society. The link between these diseases and diabetes and obesity (often referred to as diabetes type 3 ) should alarm us further.

\section{Obesity}

Obesity rates continue to climb, ${ }^{7}$ and a recent study re-emphasised that increased obesity is associated with shorter longevity and significantly increased risk of cardiovascular morbidity and mortality. ${ }^{8}$ Though rarely recorded as a cause of death, obesity is often linked to cardiovascular disease and significantly increases the risk of at least 13 cancers. ${ }^{9}$

Cancer Research UK states that after smoking, obesity is the biggest cause of cancer, linked to about 23000 additional cases annually. ${ }^{10}$ For the US, a 2017 report by the Centers for Disease Control and Prevention indicates that cancers associated with overweight and obesity make up $40 \%$ of cancers diagnosed. ${ }^{11}$

\section{Nutrition}

As much as genetics plays an important part in a person's susceptibility to overweight, obesity, or diabetes, nutrition is certainly the key driver. The evidence of what is or should be recommended to healthy people or those with metabolic disease is still confusing, contradictory, and, in fact, calamitous.

Recent studies show that weight loss and remission of diabetes can be achieved through dietary changes. ${ }^{12-14}$ Our understanding of nutrition is often poor because of evidence that is conflicting and sometimes influenced by vested interests. This in turn leads to questionable downstream policy decisions that massively 
influence the outcome of world health, individual wellbeing, and the financial health of life insurance portfolios, not to speak of national health systems.

Swiss Re has developed a life insurance model to assess the population effect of reducing some of the longer term risk markers associated with type 2 diabetes, prediabetes, and metabolic syndrome through nutrition strategies. If all those affected followed such a nutrition strategy the model estimates an annual $13 \%$ reduction in total death claims.

For life insurers paying billions in death claims annually, a reduction of at least $13 \%$ would mean substantial gains. More importantly, for individuals and society it would reduce the premature loss of life from conditions that are preventable and reversible. May that be "food" for thought, and "medicine" to help make the world more resilient.

Competing interests: JS is a board member of the Nutrition Coalition. Both authors are employed by Swiss Re.

Provenance and peer review: Commissioned; not externally peer reviewed.

This article is one of a series commissioned by The BMJ. Open access fees for the series were funded by SwissRe, which had no input in to the commissioning or peer review of the articles. The BMJ thanks the series advisers, Nita Forouhi and Dariush Mozaffarian, for valuable advice and guiding selection of topics in the series.

1 Insured Retirement Institute. IRI Fact Book 2017. http://investor.metlife.com/phoenix zhtml?c=121171\&p=irol-SECText\&

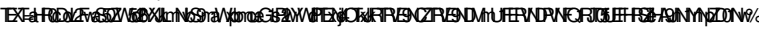
$3 \mathrm{D} \% 3 \mathrm{D}$

2 Institute and Faculty of Actuaries. CMI mortality projections model 2016 launched. $29 \mathrm{Mar}$ 2017. https://www.actuaries.org.uk/news-and-insights/media-centre/media-releases-andstatements/cmi-mortality-projections-model-2016-launched
3 Mortality in the United States, 2016. NHCS databrief No 293. 2017. https://www.cdc.gov/ nchs/data/databriefs/db293.pdf

4 Stokes A, Preston SH. Deaths attributable to diabetes in the United States: comparison of data sources and estimation approaches. PLoS One 2017;12:e0170219. 10.1371/journal.pone.0170219 28121997

5 Xu Y, Wang L, He J, etal. 2010 China Noncommunicable Disease Surveillance Group. Prevalence and control of diabetes in Chinese adults. JAMA 2013;310:948-59. 10.1001/jama.2013.16811824002281

6 International Diabetes Federation. IDF Diabetes Atlas. 2015

7 NCD Risk Factor Collaboration (NCD-RisC). Worldwide trends in body-mass index, underweight, overweight, and obesity from 1975 to 2016: a pooled analysis of 2416 population-based measurement studies in 128.9 million children, adolescents, and adults. Lancet 2017;390:2627-42. 10.1016/S0140-6736(17)32129-3 29029897

8 Khan SS, Ning $\mathrm{H}$, Wilkins JT, etal . Association of body mass index with lifetime risk of cardiovascular disease and compression of morbidity. JAMA Cardiol 2018;3:280-7. 10.1001/jamacardio.2018.0022 29490333

9 Lauby-Secretan B, Scoccianti C, Loomis D, Grosse Y, Bianchini F, Straif KInternational Agency for Research on Cancer Handbook Working Group. Body fatness and cancer-viewpoint of the IARC Working Group. N Engl J Med 2016;375:794-8. 10.1056/NEJMsr1606602 27557308

10 Cancer Research UK. Obesity, weight and cancer. http://www.cancerresearchuk.org/ about-cancer/causes-of-cancer/obesity-weight-and-cancer

11 CDC. Cancers associated with overweight and obesity make up 40 percent of cancers diagnosed in the United States. Press release, 3 Oct 2017. https://www.cdc.gov/media/ releases/2017/p1003-vs-cancer-obesity.html

12 Hallberg SJ, McKenzie AL, Williams PT, etal . Effectiveness and safety of a novel care model for the management of type 2 diabetes at 1 year: an open-label, non-randomized, controlled study. Diabetes Ther 2018;9:583-612.29417495

13 Lean MEJ, Leslie WS, Barnes AC, etal . Primary care-led weight management for remission of type 2 diabetes (DiRECT): an open-label, cluster-randomised trial. Lancet 2018;391:541-51. 10.1016/S0140-6736(17)33102-1 29221645

14 Unwin DJ, Cuthbertson DJ, Feinman R, Sprung VS. A pilot study to explore the role of a low-carbohydrate intervention to improve GGT levels and HbA1c. Diabesity in Practice 2015;4:102-8.

Published by the BMJ Publishing Group Limited. For permission to use (where not already granted under a licence) please go to http://group.bmj.com/group/rights-licensing/ permissions This is an Open Access article distributed in accordance with the Creative Commons Attribution Non Commercial (CC BY-NC 4.0) license, which permits others to distribute, remix, adapt, build upon this work non-commercially, and license their derivative works on different terms, provided the original work is properly cited and the use is non-commercial. See: http://creativecommons.org/licenses/by-nc/4.0/. 